\title{
THE "SITTING" POSITION AND ITS IMPLICATIONS IN DENTAL TECHNOLOGY. GENERAL ASPECTS OF IMPROVING THE QUALITY OF LIFE - PART II
}

\author{
CLAUdIA-CAMELIA BURCEA ${ }^{1}$, MĂDĂLINA VIOLETA PERIEANU ${ }^{2}$, MIHAI BURLIBAȘA ${ }^{3}$, \\ RADU COSTEA ${ }^{4}$, VIOREL ȘTEFAN PERIEANU ${ }^{5}$, GABRIELA TĂNASE ${ }^{5}$, CAMELIA IONESCU $^{6}$, \\ IULIANA BABIUC ${ }^{7}$, IOANA-CRISTINA NEAGOE ${ }^{8}$, RALUCA COSTEA ${ }^{9}$, AUGUSTIN MIHAI ${ }^{10}$, \\ MAGDALENA NATALIA DINA ${ }^{11}$, MĂDĂLINA ADRIANA MALIȚA ${ }^{12}$, GABRIELA TĂNASE $^{13}$, \\ ELENA-CRISTINA MARCOV ${ }^{14}$, MIHAELA CHIRILA ${ }^{15}$
}

1,2,3,4,5,6,7,10,11,12,13,14,15 “Carol Davila” University of Medicine of Pharmacy Bucharest, Romania, ${ }^{8}$ University of Pitești, ${ }^{9}$ Dental Practice Brașov

Keywords: dental Abstract: Nowadays, at work, many people spend more than half of their entire day working in a technician, quality of life, sitting position. Maintaining this position for a long period of time is a risk factor for health. The sitting position results of various studies have shown associations between maintaining a prolonged sitting position with morbidity due to chronic diseases, such as cardiovascular disease, diabetes, metabolic syndrome, obesity, etc. And, as we have already mentioned in the first part of this study, dental technicians are part of this category of staff, who carry out most of their specific activity, in a sitting position.

\section{INTRODUCTION}

As we mentioned in the first part of this paper, presented in a previous issue of the journal Acta Medica Transilvanica, dental technology is a profession that requires great accuracy from those who practice it, this profession taking place in over $90 \%$ of the time, in a sitting position. Also, as we mentioned in the first part of this material, in the context of implementing in the period 2016-2019 of solid ergonomic principles among this category of staff, either through welldocumented specialization courses held within professional organizations, or through up-to-date specialized literature.

Nowadays, at work, many people spend more than half of their entire day working in a sitting position. Maintaining this position for a long time is a risk factor for health. The results of various studies have shown associations of maintaining a prolonged sitting position with morbidity due to chronic diseases, such as cardiovascular disease, diabetes, metabolic syndrome, obesity, etc.(1-4) And, as already mentioned, dental technicians are part of this category of staff, who carry out most of their specific activity, in a sitting position.

\section{AIM}

The large proportion, and ever-increasing number of employees who have static office activity (in our case, dental technician table), represents a significant number of workers potentially exposed to risks to their health.

Office work (and/or table work, in our case we are talking about the dental technician table) is widely perceived as a risk factor for musculoskeletal disorders, which have become among the most commonly diagnosed occupational diseases in many countries of the world. Risk factors for musculoskeletal disorders include socio-demographic characteristics (age, gender) and other personal characteristics (height, weight, smoking, tendency to somatise), as well as psychosocial, organizational and physical aspects of work (duration of work, rest period, possibilities for regular breaks, exercise, etc.).(4-7)

In order to perform the analysis of body position, some extremely important aspects must be taken into account, such as: positioning of body segments, support polygon or support base, position of centre of gravity and maintaining balance, ratios of biomechanical axes of segments, osteoarticular levers, muscle groups in labour, passive stabilization, position variants related to individual morphological characteristics, etc.

The way an employee works, the posture he adopts, leads to complications of the effects of the sedentary nature of their work. Prolonged vicious positions will accelerate or exacerbate the development of musculoskeletal symptoms.

Musculoskeletal function, being related to physical capacity, is one of the factors that affect the balance between work requirements and the performance capacity of the worker.

The clinical and functional assessment of musculoskeletal disorders should include aspects such as severity, frequency and intensity of pain, in order to establish measures that can contribute to the prevention, treatment and prognosis of these disorders. Ergonomic intervention can have a positive impact on musculoskeletal disorders, one of the objectives of ergonomics being to improve worker performance, reduce stress and fatigue at work. In ergonomics, the posture and movement of a worker are important information to determine the risk of developing musculoskeletal disorders at work.(7-9)

Through kinetic and ergonomic intervention but also the improvement of the working environment, musculoskeletal injuries can be prevented among office workers.(10-13)

Changes in the positions of different body segments play an important role both in terms of posture and in the discomfort associated with prolonged sitting position.(10-17)

${ }^{4}$ Corresponding author: Radu Costea, Str. Plevnei, Nr. 19 Sector 1, Bucureşti, România, E-mail: mburlibasa@gmail.com, Phone: +40723472632 Article received on 25.10.2020 and accepted for publication on 15.12.2020 


\section{CLINICAL ASPECTS}

Starting not only from these aspects that we presented in this second part of the paper, but also taking into account the extremely relevant reasons that represented the purpose of the first part of the study, we can actually list the overall objectives of this material, we consider new, extremely interesting:

- $\quad$ Posture and body alignment screening for the selected target group;

- Evaluation of the most frequent positions of the body segments, during the professional activity;

Identification of risk factors associated with office work;

- Identification of possible musculoskeletal disorders among people who have specific professional activity for office work.

\section{MATERIALS AND METHODS}

As we have already mentioned in the first part of the material, for this study we chose the questionnaire method. It has a number of advantages, such as:

- Speed and convenience of obtaining indicative information for prospecting;

Opinion trends;

Sincerity of answers, due to anonymity and confidentiality;

Capturing the influence of a facilitating and disturbing factor, before the effects are actually visible.

The completed questionnaire was divided into two parts. The first part of the questionnaire with the related conclusions has already been published in a previous issue of the journal Acta Medica Transilvanica, the second part will be presented in this material. As in the previous report, this questionnaire was applied to a number of 61 dental technicians aged between 31 and 67 years, between August and September 2019. The study group came mainly from Bucharest, but were and subjects working in Brașov, Constanța, Sibiu, Pitești, Alexandria and Râmnicu Vâlcea. 37 of the subjects were female (60.66\%), while 24 of the subjects were male (39.34\%).

If the first part of the questionnaire applied to dental technicians referred to issues such as the number of working hours per day; the number of working days per week; work table height; working chair height and ergonomics; the positions of the head, neck, body, upper and lower limbs during working hours; the angles at which the elbows, wrists, hips, knees and ankles are maintained during the work programme, as well as how the body weight is distributed over the hips during the work programme, in the second part of the questionnaire, other very interesting problems were approached, but also extremely conclusive from the daily activity not only of a dental technician, but even of an employee who carries out daily activity in a sitting position at the office. Specifically, we discuss of:

Frequency of changing body position during work;

- Number, duration and frequency of breaks during the working hours;

Way of spending time during breaks in working hours;

Distance between home and work and vice versa;

Ways to get from home to work and from work to home;

Suffering caused by work;

Painful areas caused by work;

Frequency and duration allocated to physical activities (exercises);

- The reason for not performing physical activities (exercises);

Interest in maintaining a correct position;

Body weight;

Body height;

How the work performed influenced body weight;

The way in which the body weight had an influence on the development of the professional activity, etc.
Next, we will present the second part of the questionnaire developed by us:

1. Have you followed in the period 2016-2019, in your professional training, courses in ergonomics and / or occupational disease prevention or have studied up-todate literature? a. yes; $\boldsymbol{b}$. no.

2. How often do you change your body position during the work schedule? a. Very often; $\boldsymbol{b}$. often; $\boldsymbol{c}$. rare; $\boldsymbol{d}$. very rarely; $\boldsymbol{e}$. I can't appreciate.

3. How do you assess the length of the brake time during the working day? a. insufficient; b. sufficient; $\boldsymbol{c}$. average; $\boldsymbol{d}$. large; $\boldsymbol{e}$. it's very big; $\boldsymbol{f}$. I can't appreciate.

4. What is the frequency of breaks during the working programme? a. every hour; b. at 2 o'clock; c. more than 2 hours; $\boldsymbol{d}$. when you feel the need; $\boldsymbol{e}$. I can't appreciate.

5. How do you spend the time allocated to breaks during the working programme? a. eating; b. drink coffee; c. move; d. you simply relax; e. I can't appreciate, because I approach all the previously presented variants.

6. How do you appreciate the distance from home to work? a. very small; b. small; c. far; d. very far; e. I can't appreciate.

7. What are the ways to get from home to work and back home? a. personal car; b. means of public transport; $\boldsymbol{c}$. walking; d. others (bicycle, electric scooter, etc.); $\boldsymbol{e}$. do I alternate the means of travel (car - walking; walking cycling, etc.).

8. Do you consider that your work has caused you various sufferings - symptoms caused by work? a. yes; b. no; c. I can't appreciate.

9. What are the areas where you feel pain caused by the activity of dental technician? a. neck/cervical spine; $\boldsymbol{b}$. back/thoracic spine; c. lumbar area/lumbar spine; d. the entire upper limb; $\boldsymbol{e}$. arm/forearm; $\boldsymbol{f}$. shoulder; g. elbow; $\boldsymbol{h}$. the joint (wrist) of the hand; $\boldsymbol{i}$. fingers; $\boldsymbol{j}$. the lower limb as a whole; $\boldsymbol{k}$. thigh/leg; l. hip; $\boldsymbol{m}$. knees; $\boldsymbol{n}$. ankle; o. I can't appreciate.

10. How much time do you spend on physical activities physical exercises? a. A lot; b. much; $\boldsymbol{c}$. sufficient; d. little; $\boldsymbol{e}$. very little; $f$. I can't appreciate.

11. What are the reasons for not doing physical activities physical exercises? a. lack of time; $\boldsymbol{b}$. convenience; $\boldsymbol{c}$. habit; $\boldsymbol{d}$. I can't appreciate.

12. How do you appreciate your interest in maintaining a correct position? a. Very small; b. small; c. medium; d. large; $\boldsymbol{e}$. it's very large; $\boldsymbol{f}$. I can't appreciate?

13. How did the body weight change after starting the activity as dental technician? a. decreased; $\boldsymbol{b}$. was maintained; $\boldsymbol{c}$. has grown; $\boldsymbol{d}$. I can't appreciate.

14. How do you appreciate the influence of body weight on work? a. very high; b. large; c. not at all; $\boldsymbol{d}$. small; $\boldsymbol{e}$. very small; $f$. I can't appreciate?

\section{RESULTS}

By applying the questionnaire, the following results were obtained:

All subjects took courses in ergonomics and/ or occupational disease prevention in 2016-2019 period. About changing the body position during the work schedule, 20 subjects do this very often, 20 subjects often and 21 subjects could not appreciate.

42 of the respondents (representing 68.85\%) considered that the length of the break times is average, while 19 (representing 31.15\%) respondents could not assess its duration. Regarding brake time frequency, 15 study participants (representing 24.59\%) take these breaks every hour, 12 participants every two hours, 22 participants when they feel the 


\section{CLINICAL ASPECTS}

need, while 12 participants can not appreciate this.

Figure no. 1. Changing body position during the work schedule among respondents

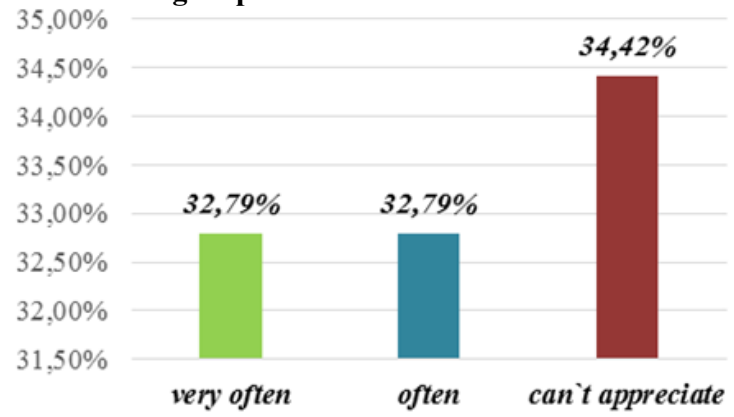

Figure no. 2. Assessing length of the break time during work schedule

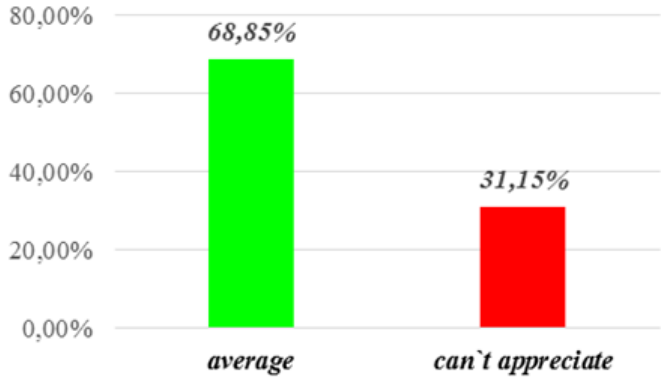

Figure no. 3. The interval at which study participants take breaks during the programme

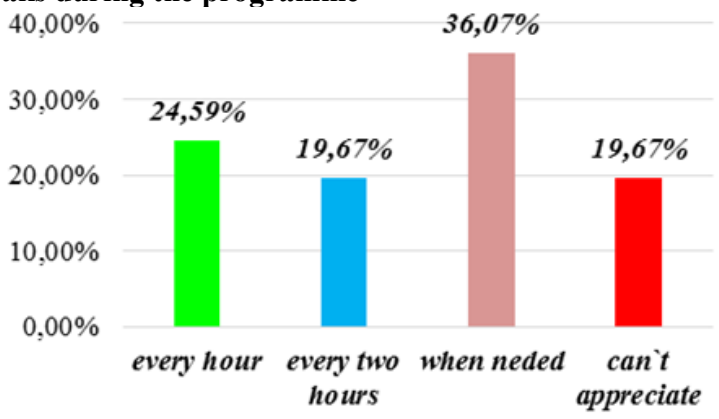

Concerning the way of spending time during brake all the participants mentioned that they do not have a specific way, all the other answer variants being correct depending on a certain moment of the day.

Figure no. 4. The distance travelled from work to home by study participants

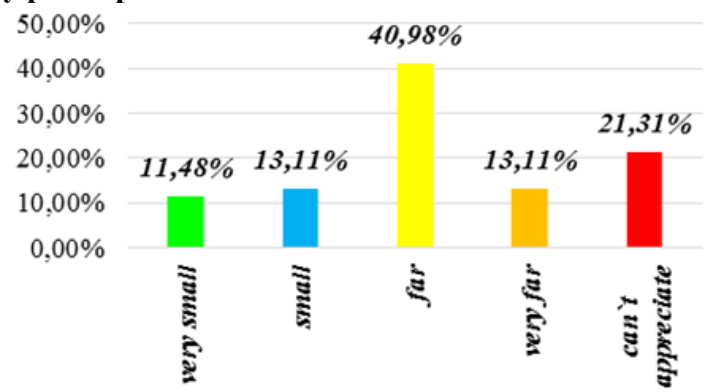

The distance between the workplace and the home of the study participants is represented in Figure 4

Regarding the traveling methods from home to work and back, all respondents use other options besides personal car, public transport or walking.
An important aspect we notice by the unanimous answer given by the respondents through which the work they do every day has caused various sufferings - symptoms.

Although we would have expected respondents to specifically indicate a certain painful region caused by the work as a dental technician, all respondents ticked several regions predominantly in the upper part of the body along with the knees.

As expected, physical activities are not a priority for the practitioners involved in the study, 10 of them allocate enough time, the majority (39 representing 63.93\%) allocate little time, while 12 cannot appreciate the time allocated.

Figure no. 5. Time allocated for physical activities - physical exercises

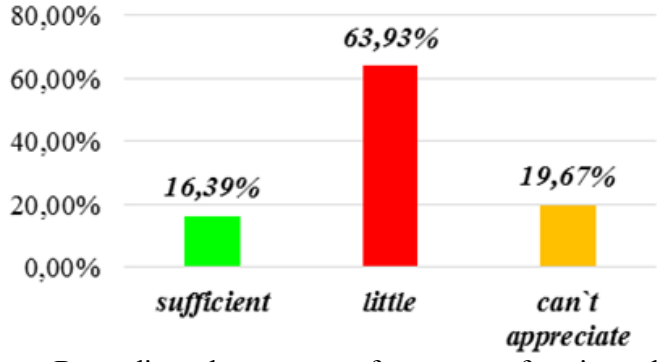

Regarding the reasons for not performing physical activities, 23 subjects (representing 37.70\%) complained about the lack of time, 18 (representing 29.51\%) out of convenience, the remaining 20 subjects (representing 32.79\%) could not appreciate the exact reason.

Figure no. 6. The reasons why the respondents did not perform the physical activities

$80,00 \%$

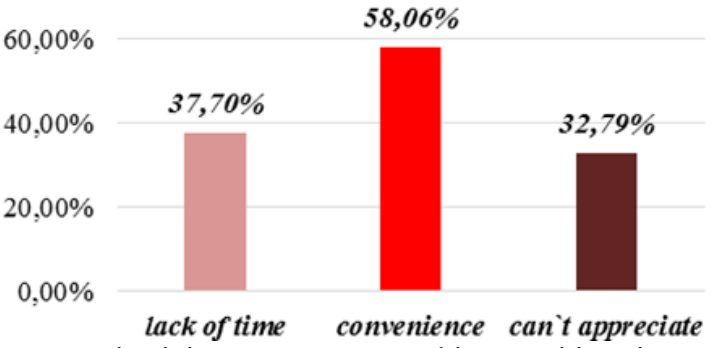

Maintaining a correct working position is a real concern for the vast majority of respondents (53), only for 8 respondents it is a medium level concern.

Sedentary activity and the lack of physical activities from the beginning of the dental technician profession, as all the respondents appreciated, led in time to the weight gain. This, although it occurred gradually over time, was felt in the daily activities at work.

Figure no. 7. Interest in maintaining a correct working position

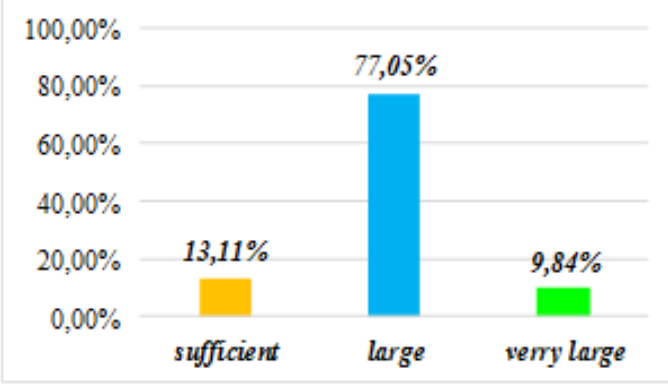




\section{CLINICAL ASPECTS}

CONCLUSIONS

Analysing the answers from the second part of the questionnaire, we can conclude the following aspects:

- Musculoskeletal disorders are very common among dental technicians.

- Reducing the extended time of maintaining a sitting position at work, as well as controlling body position (maintaining a correct posture) can contribute to improving the results of prophylaxis of the health of employees with sedentary jobs, also of dental technicians, especially with the reduction of back and neck pain, the improvement of general comfort and the influence of the general mood (positive emotion, well-being).

- Proper working posture and ensuring healthy working conditions can make work easier and more relaxed, thus contributing to improving the quality of life and increasing performance at work.

- It is imperative to take into account some aspects of the effects on the health of dental technicians, in order to preventively intervene in possible specific pathologies, establishing a strategy against occupational diseases.

- Physical activity (exercise) should be encouraged through occupational health promotion programmes. Primary kinetic prophylaxis programmes aim to reduce the discrepancy between the workload and the physical capacity of the dental technician. Physical fitness training will improve individual physical capacity to cope with the volume of physical work. Secondary kinetic prophylaxis programmes (stopping the further development of musculoskeletal disorders) and tertiary kinetic prophylaxis programmes aim to: reduce pain related to musculoskeletal disorders and improve the functional status of the worker.

- Exercise programmes, rigorously designed and adapted to individual needs, are important measures in preventing/ameliorating musculoskeletal disorders, cardiovascular disease, diabetes, metabolic syndrome and obesity caused by work, with positive effects in reducing the morbidity of office workers.

\section{Acknowledgement:}

In this article, all the authors have equal contributions.

\section{REFERENCES}

1. Burcea CC, Perieanu MV, Perieanu VS, Burlibașa M, Tănase G, Ionescu C, Babiuc I, Cristache CM, Costea R, Donciu I, Oancea L, Ionescu I, Marcov EC, Maliț M, Beuran IA. The "sitting" position and its implications in dental technology. General aspects of improving the quality of live - Part I. Acta Medica Transilvanica. 2020;25(3):6974.

2. Cho IY, Park SY, Park JH, et al. The effect of standing and different sitting positions on lumbar lordosis: Radiographic study of 30 healthy volunteers. Asian Spine J. 2015;9(5):762-769.

3. Pronk NP, Katz AS, Lowry M, Payfer JR. Reducing occupational sitting time and improving worker health: The Take-a-Stand Project, 2011. Prev Chronic Dis. 2012;9:E154.

4. Nakhaie MR, Koor BE, Salehi SO, Karimpour F. Prediction of cardiovascular disease risk using framingham risk score among office workers, Iran, 2017. Saudi J Kidney Dis Transpl. 2018;29:608-14.

5. Burcea CC, El-Rifai N, Burlibașa M, et al. Aplicaţii ale kinetoterapiei în suprasolicitarea coloanei vertebrale toraco-lombare prin poziție de lucru vicioasă în activitatea profesională specifică a tehnicienilor dentari. În: Probleme în medicină și biologie, coordonatori: Burcea CC, Dumitru
SG, Costea R, et al. Editura Ars Docendi, București, 2017;7:311-328.

6. Habibi E, Shiva S. The effect of three ergonomics interventions on body posture and musculoskeletal disorders among stuff of Isfahan Province Gas Company. J Edu Health Promot. 2015;4:65.

7. Dinar A, Susilowati IH, Azwar A, et al. Analysis of ergonomic risk factors in relation to musculoskeletal disorder symptoms in office workers. KnE Life Sciences. 2018 4(5):16-29.

8. Hagberg M, Violante FS, Bonfiglioli R, et al. Prevention of musculoskeletal disorders in workers: Classification and health surveillance - statements of the Scientific Committee on Musculoskeletal Disorders of the International Commission on Occupational Health. BMC Musculoskelet Disord. 2012;13:109.

9. Mohammadipour F, Pourranjbar M, Naderi S, Rafie F. Work-related musculoskeletal disorders in Iranian office workers: Prevalence and Risk Factors. J Med Life. 2018;11(4):328-333.

10. Lee J, Koo JW. Occupational diseases among office workers and prevention strategies. J Ergon Soc Korea. 2015; 34(2): 125-134.

11. Sheeran L, Hemming R, Van Deursen R, Sparkes V. Can different seating aids influence a sitting posture in healthy individuals and does gender matter? Cogent Eng. March 2018. 5(1): 1442109

12. Burcea CC, Georgescu L, Burlibașa M et al. Chestionar destinar orientării strategiei de intervenție profilactică și terapeutică în scopul creșterii performanței la locul de muncă a specialiștilor din domeniul tehnicii dentare. În: Probleme în medicină și biologie, Vol. 2, Editura Ars Docendi, Bucureşti, 2014: 11-62, coordonatori: Burcea C.C., Ionescu C., Cristache C.M., Burlibașa L.

13. Burcea CC, Georgescu L, Popovici IA, et al. Chestionar test de identificare a nivelului de fitness a specialiștilor din domeniul tehnicii dentare. În: Probleme în medicină și biologie, Vol. 3, Editura Ars Docendi, Bucureşti, 2014: 95 141, coordonatori: Bodnar D.C., Burcea C.C., Popovici I.A., Comănescu C.

14. Eșian D, Man A, Burlibașa L, Burlibașa M, Perieanu MV, Bică C. Salivary level of Streptococcus mutans and Lactobacillus spp. related to a high risk of caries disease. Rom Biotechnol Lett. 2017;22(2):12496-12503.

15. Ionescu CA, Popovici LR, Mocuța D, Malița C, Burlibașa M. The quality of human life from the perspective of sustainable development Metalurgia International. 2009; 14:41-43.

16. Mocuța D, Popovici IA, Burlibașa L, Cristache G, Sfeatcu $\mathrm{R}$, Bodnar T. Impact of the living conditions on population health. Metalurgia International. 2009;14:17-19.

17. Mocuța D, Popovici IA, Burlibașa L, Cristache G, Sfeatcu $\mathrm{R}$, Bodnar T. Impact of the living conditions on population health. Metalurgia International. 2009;14:17-19. 